PontIFícIA UNIVERSIDADE CATÓLICA dO RIO DE JANEIRO

\title{
Cidades Inteligentes e Gentrificação: uma análise do Projeto Porto Maravilha
}

Paula Dantas Wangler

Trabalho de Conclusão de Curso

Centro de CiÊnCIAS SOCIAIS - CCS

DePARTAMENTO de AdMinistraçÃo

Graduação em Administração de Empresas 


\section{Cidades Inteligentes e Gentrificação: uma análise do Projeto Porto Maravilha}

Trabalho de Conclusão de Curso

Trabalho de Conclusão de Curso, apresentado ao programa de graduação em Administração da PUC-Rio como requisito parcial para a obtenção do titulo de graduação em Administração.

Orientador(a) : Edmundo Eutrópio

Rio de Janeiro junho de 2017. 


\section{Agradecimentos}

Aos meus pais e minha irmã pelo amor e apoio incondicional.

Ao meu melhor amigo, Filipe, por sempre acreditar em mim.

À minha família e amigos por entenderem a minha ausência nos encontros.

Ao Edmundo, por ter me tranquilizado o período todo.

Por fim e mais importante, à Deus por me dar forças para concluir este trabalho. 


\section{Resumo}

Wangler, Paula. Cidades Inteligentes e Gentrificação: uma análise do Projeto Porto Maravilha. Rio de Janeiro, 2017, 33 p. Trabalho de Conclusão de Curso - Departamento de Administração. Pontifícia Universidade Católica do Rio de Janeiro. Souza, Edmundo Eutrópio (Orientador).

Cidades inteligentes ou smart cities são aquelas que colocam o cidadão no centro do desenvolvimento e planejamento urbano através da ajuda da tecnologia da informação e comunicação. As cidades inteligentes são as novas tendências mundiais. Para ser realizada com sucesso, as cidades inteligentes precisam de planejamento e organização por parte do governo. Caso contrário, o despreparo pode causar problemas graves com os cidadãos como a gentrificação. Para entender melhor como funciona esse processo e quais as vantagens e desvantagens de ter a tecnologia a favor da sociedade, esse estudo de caso analisou o Projeto do Porto Maravilha para entender as resultantes dessa nova tendência mundial.

\section{Palavras- chave}

Cidades Inteligentes; Gentrificação; Porto Maravilha.

\section{Abstract}

Smart cities are those that place citizens at the center of urban development and planning through the help of information and communication technology. Smart cities are the new world trends. To be successful, smart cities need planning and organization by the government. Otherwise, unpreparedness can cause serious problems with citizens such as gentrification. To better understand how this process works and what are the advantages and disadvantages of having technology in favor of society, this case study analyzed the Porto Maravilha Project to understand the results of this new world trend.

\section{Key-words}

Smart Cities; Gentrification; Porto Maravilha 


\section{Sumário}

1. O tema e o problema de estudo 1

1.1. Introdução ao tema e ao problema do estudo 1

2. Contexto e realidade Investigada 4

2.1. Cidades Inteligentes: conceito, desafios e benefícios 4

2.1.1. Sem mais buzinas!| Nova York X Trânsito 8

2.1.2. Pequena enorme cidade | Dubuque X Agua, Luz e Gás 9

2.1.3. Placas Solares | Apple de Dubai 10

2.1.4. Unlimited Stadium | Nike Filipinas 10

2.1.5. Distrito 22@ Barcelona 11

2.2. Gentrificação: causas e consequências 14

3. Projeto Porto Maravilha 18

3.1. Contexto 18

3.1.1. Imersão | A real necessidade 19

3.1.1.1. Trabalhadores Locais 20

3.1.1.2. Moradores da Região $\quad 21$

3.1.1.3. Turistas 23

3.1.1.4. Governo e outras Empresas 23

4. Propostas de Melhoria | Projeto Porto Maravilha 25

4.1. Trabalhadores locais 28

4.2. Moradores locais 29

4.3. Turistas 30

5 Conclusão 32

6. Referências Bibliográficas 34 


\section{Lista de figuras}

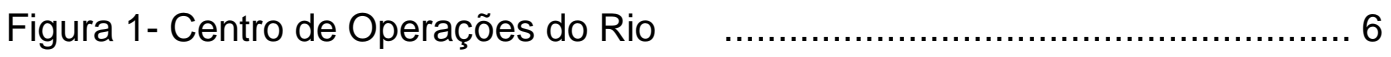

Figura 2 - Sensores para evitar o desperdício $\quad$........................................... 9

Figura 3 - Apple de Dubai com Placas Solares inteligentes $\quad$.......................... 10

Figura 4 - Distrito 22@ de Barcelona e suas divisões $\quad$................................... 12

Figura 5 - Bueiros com sensores no Porto Maravilha $\quad$................................ 27 


\section{O tema e o problema de estudo}

\subsection{Introdução ao tema e ao problema do estudo}

Segundo uma pesquisa realizada pela Organização das Nações Unidas (ONU), 54,6\% da população do planeta já vive em cidades. Esse mesmo estudo aponta que em 2050, esse número aumentará para 70\% (2016, BID). Ao mesmo tempo que acontecia essa inflação na área urbana, observou-se que o número de dispositivos conectados ultrapassou o número de pessoas no mundo. Atualmente, somos 7,5 bilhões no planeta contra 50 bilhões de dispositivos conectados (2011, EVANS, D.). Hoje em dia, já é possível nomear os dois grandes responsáveis por essa transformação: a revolução digital e a aceleração da urbanização global.

Com o avanço dessa nova era, a revolução digital transformou a forma como o homem interagia com o mundo e como o mesmo absorvia as informações. Em pouco tempo, a digitalização mostrou os dois lados dessa nova tendência: o negativo que seria a substituição da produção manual por produção digital e o positivo que seria a imensurável quantidade de informações disponíveis para toda sociedade a qualquer momento. $\mathrm{O}$ outro agente dessa mudança foi a aceleração urbana. Segundo a ONU, esse fator é um dos mais preocupantes visto que essa migração ocorreu principalmente em países em desenvolvimento ou de baixa renda. Isso significa que, pessoas sem condições de manter a vida no campo, fogem em busca de emprego nas cidades e encontram um novo sentido para a palavra miséria. Essas cidades, por sua vez, não estão preparadas para receberem esse grupo e a única solução para elas é morar em favelas onde o acesso a serviços básicos é restrito. Em outras palavras, esse avanço da população na área urbana não é sustentável e nem planejado.

Felizmente, hoje em dia isso já não é mais uma preocupação em algumas cidades no mundo. Com a ajuda da Internet das Coisas, também conhecida como loT, metrópoles já são capazes de integrar o ambiente com a sociedade de forma sustentável e inteligente, criando, portanto, as novas tendências mundiais, as cidades inteligentes. Segundo o escritor Mauricio 
Bouskela, cidades inteligentes ou smart cities são aquelas que colocam o cidadão no centro do desenvolvimento e planejamento urbano através da ajuda da tecnologia da informação e comunicação (TIC). Apesar de ser um processo trabalhoso que precisa envolver um grupo grande de stakeholders para dar certo, os números mostram que essa transformação da cidade tradicional para inteligente traz benefícios a longo prazo não só para a sociedade local como também para o planeta, visto que as soluções são sempre sustentáveis. 0 principal objetivo das cidades inteligentes é solucionar os problemas do cotidiano através de soluções inovadoras e melhorar a qualidade de vida da população. Com a ajuda da Internet das Coisas, os objetos conectados transmitem dados para a rede que centraliza todas essas informações e coleta esses dados urbanos, transformando-os em informação e conhecimento. Através deles é possível controlar e monitorar a cidade como um todo, analisando como a mesma responde aos problemas do dia-a-dia.

Na teoria, para uma cidade se tornar inteligente é necessário que todos os habitantes tenham os mesmos direitos e oportunidades, independente das peculiaridades de cada pessoa ou grupo social. Na prática, esta é uma das questões mais difíceis de ser implementada. A inclusão social é uma variável que atinge não só países em desenvolvimento como também países desenvolvidos. Essa inclusão abrange desde serviços públicos como hospitais e escolas até questões menos relevantes como acesso a equipamentos tecnológicos e redes digitais. Por se tratar de um estudo a respeito da nova era da tecnologia, este trabalho não aborda os direitos básicos de cada indivíduo e sim questões relacionadas a inteligência tecnológica.

Pode-se, portanto, concluir que o grande desafio dos governos para transformar as suas cidades é a inclusão social. Quando não há planejamento por parte das autoridades, essa melhoria da qualidade de vida no local pode gerar um enorme problema para os habitantes locais: a gentrificação. Segundo o estudioso Smith, gentrificação é o evento que ocorre quando um bairro ou uma região sofre alterações de melhoria, valorizando a área e afetando a população de baixa renda do local, obrigando-os a, muitas vezes, terem que se deslocar em busca de um novo lugar para habitar.

Para entender melhor na prática como funciona o processo de transformação de uma cidade tradicional para uma cidade inteligente esse 
trabalho de conclusão de curso analisou o projeto realizado pela Prefeitura do Rio de Janeiro que transformou o Porto Maravilha em um dos bairros mais conectados e inteligentes. Com duração de 18 meses de projeto, o Porto Maravilha recebeu 15 aplicações de soluções inteligentes para conectar o público com o espaço, além de disponibilizar ferramentas que auxiliam no planejamento e controle de todo esse investimento. Apesar do sucesso do projeto, é necessário entender até que ponto esse investimento realizado trouxe, de fato, melhorias para a população local.

Em suma, o presente estudo tem como objetivo identificar se a resultante do Projeto Porto Maravilha trouxe reais benefícios pela percepção dos trabalhadores locais e moradores da região.

Por fim, esse trabalho foi fracionado em quarto partes, além da introdução já retratada. A primeira etapa aborda os dois conceitos dos principais pontos desse trabalho que é cidade inteligente e gentrificação além de mencionar exemplos de áreas, empresas e até mesmo cidade que foram transformadas com a aplicação da internet das coisas. A segunda parte foi destinada para entender o contexto que a região do Porto Maravilha estava inserida antes do desenvolvimento do projeto. A terceira etapa mostra o aprofundamento do projeto e as implementações feitas e opiniões dos principais beneficiados pela revitalização da área portuária do Rio de Janeiro. E, a quarta e última etapa foi separada para conclusão de todos os pontos levantados anteriormente. 


\section{Contexto e realidade Investigada}

\subsection{Cidades Inteligentes: conceito, desafios e benefícios}

Conforme levantado no capítulo anterior, cidades inteligentes foram criadas para elaborar respostas inovadoras para os habitantes da região. Isso é possível devido a tecnologia de sensores distribuídos pela cidade que captam os dados necessários para gerir de forma inteligente os problemas imediatos e organizar os cenários urbanos. Com essa ferramenta, por exemplo, hoje em dia, é possível controlar os semáforos para evitar engarrafamento em horários de rush ou até otimizar processos para diminuir o tempo de espera de uma fila no hospital. Segundo o estudo realizado pelo BID, em síntese, as cidades inteligentes se diferenciam das cidades tradicionais por gerarem integração entre a administração pública com tecnologia fazendo a informação chegar de forma mais clara, relatarem procedimentos comuns que aumentam a eficiência do governo, otimizam alocação de recursos, melhoram o relacionamento entre cidadão e administração pública, criam novos indicadores que auxiliam na medição das políticas públicas.

O grande diferencial das cidades inteligentes é que a cidade, como um todo, se comunica, desde a gestão pública até a infraestrutura dos apartamentos e casas. As questões principais que precisam ser solucionadas para acontecer a transformação de cidade tradicional para cidade inteligente são os aspectos humanos, sociais e ambientais dos centros urbanos a fim de melhorar a vida da população. Dessa forma, as smart cities precisam incorporar aspectos relativos à governança, à infraestrutura e ao capital humano e social. Para se ter um ambiente adequado para se ter uma cidade inteligente, são necessários quatro pontos cruciais:

- A cidade precisa ser sustentável: essa questão, por décadas, foi deixada de lado por não acreditarem que a sustentabilidade fosse algo relevante e que trouxesse lucro para as cidades. Hoje em dia já é possível enxergar que uma cidade sustentável não 
somente cria um ambiente propício para as gerações futuras como também reduz os custos e otimiza o consumo desnecessário.

- A cidade precisa ser inclusiva e transparente: ao criar um ambiente aberto para o diálogo entre autoridades e cidadãos, a cidade mostra que a opinião da população é importante. É necessário a criação de canais de comunicação direto onde seja possível, também, verificar e acompanhar os gastos públicos.

- A cidade precisa gerar riquezas: essa questão deveria ser 0 resultado da criação de uma cidade inteligente. Ao oferecer uma infraestrutura adequada, o ambiente atrai novos negócios gerando empregos de melhor qualidade, aumentando a competitividade.

- A cidade é feita para os cidadãos: por fim, uma cidade inteligente só é considerada inteligente quando ela é feita para as pessoas. Toda essa tecnologia é criada para melhorar a qualidade de vida das pessoas, seja essa qualidade relacionada ao trabalho, meio de transporte, saúde ou lazer.

Todas as questões levantadas acima são premissas para que essa transformação ocorra de forma planejada e seja bem sucedida. Diante disso, foi realizado um estudo para entender quais métodos e procedimentos são necessários para que essas premissas aconteçam. Como o foco deste trabalho é tecnologia, as questões abaixo girarão em torno desse campo.

Do ponto de vista tecnológico, uma cidade inteligente precisa ter uma infraestrutura de conectividade, ou seja, redes de internet que consiga receber e enviar dados para todos os cidadãos. Além disso, é necessário que existam sensores capazes de captar diferentes sinais do ambiente. Esses dispositivos conectados tem como principal função transmitir essas informações e enviar para uma central para que ela possa ter o controle dos diversos campos integrados da cidade como o trânsito, atendimento ao público, saúde, segurança alerta aos desastres naturais e etc.; no Rio de Janeiro já é possível observar um pouco como isso funciona. O Centro de Operações do Rio (COR), como pode-se observar na figura 1, conta com a ajuda de mais de 1000 câmeras espalhadas 
pela cidade que mostram o que está acontecendo no perímetro urbano e, através das imagens, é possível analisar todos os dados coletados e entender melhor questões como o trânsito, segurança pública e saúde, por exemplo. Além disso, é necessário ter centros integrados de operação e controle que consigam receber, processar e analisar os dados anteriormente citados, compilá-los e repassá-los para a população. Por fim, criar um canal de comunicação onde é possível trocar opiniões e informações tanto por parte do governo para a população quanto vice-versa. Esse mecanismo favorece a gestão participativa e a transparência da gestão pública.

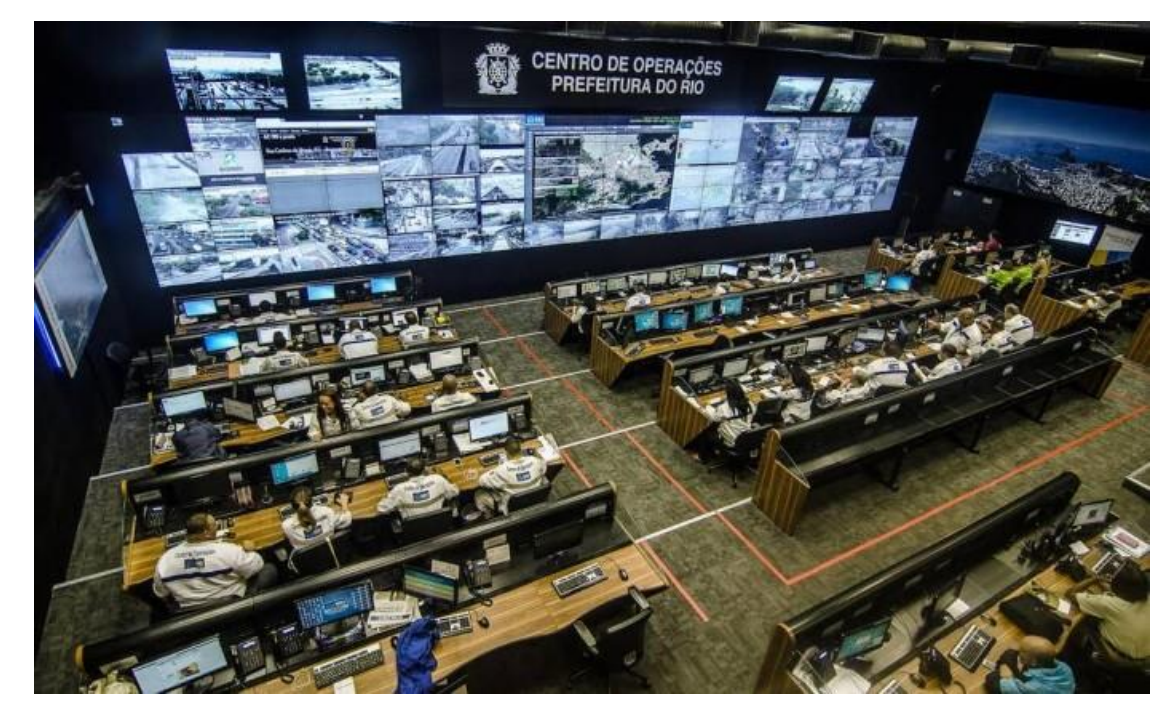

Figura 1- Centro de Operações do Rio

fonte: oglobo

Além desses grandes desafios que uma cidade tradicional precisa enfrentar para haver a transformação, as grandes cidades contam com um problema preocupante que se estende desde o início da era digital: o crescimento desgovernado da população local. Com o rápido aumento do número de habitantes em um espaço delimitado, surgem questões como qualidade de vida das pessoas, infraestrutura, segurança, educação, saúde, sustentabilidade, ou seja, surgem problemas que afetam as condições mínimas necessárias para se viver bem em um local. Para reduzir ao máximo esse contratempo, as smart cities têm o desafio de melhorar a sua capacidade fiscal. Por mais abrangente que seja esse desafio, com uma fiscalização adequada e em dia é possível ter um controle dos gastos públicos e direcioná-los para os projetos ou áreas mais necessitadas. Quando não há planejamento por parte do governo e/ou controle dos gastos, a cidade acaba não recebendo o investimento planejado para melhorar as questões acima citadas. 
De uma forma mais ampla, o desafio de se tornar uma cidade inteligente não está apenas em buscar soluções inovadoras para o dia-a-dia da população; está em conseguir progredir até esse patamar de forma a atingir um equilíbrio sustentável no âmbito urbano, ambiental, fiscal e de governança. A maior dificuldade no meio urbano é diminuir a desigualdade social, ou seja, é distribuir os serviços que a cidade oferece como transporte, educação, energia e saúde, de forma igualitária a todos. No campo ambiental, a questão que causa uma preocupação maior é o impacto causado no meio ambiente por causa do excesso de lixo e destruição do espaço físico. Com o aumento da população residente das cidades, aumenta, consequentemente, o consumo, o lixo, a poluição e tudo isso afeta o meio ambiente diretamente. Por fim, as questões fiscais e de governança dizem respeito ao poder público ser transparente com a administração e com o dinheiro da população. Ter uma administração transparente significa ser capaz de repassar para a população todos os gastos que o governo está tendo para criar um ambiente mais próspero e melhor de se viver.

Através da análise dos dados emitidos pelos sensores conectados por toda a cidade, as smart cities conseguem resolver de uma forma imediata problemas do cotidiano como o trânsito, segurança e desigualdade social e até mesmo impedir que novos contratempos aconteçam. Segundo o estudo feito pela BID, para uma cidade tradicional se tornar uma cidade inteligente, ela precisa realizar esses seis processos:

- $\quad$ Fazer com que a informação gerada chegue de forma clara e transparente para a administração pública ter um melhor resultado na gestão;

- $\quad$ Agilizar processos de atendimento em todas as redes públicas, como escolas e hospitais;

- Cortar todos os gastos desnecessários e aperfeiçoar a alocação de recursos;

- Aumentar a eficiência do governo através da otimização de processos; 
- Transformar todos os dados emitidos pela rede em indicadores de desempenho;

- Integrar a sociedade com o poder público de uma forma que as pessoas tenham um controle maior sobre o que está acontecendo na sua cidade através do total acesso às informações.

Todas essas barreiras levantadas acima impedem que o avanço das smart cities seja tão grande quanto o avanço da tecnologia. Contudo, não há mais dúvidas que o mundo está caminhando para essa direção. Para visualizar melhor e entender como funciona a dinâmica de uma cidade inteligente, os parágrafos seguintes foram destinados a exemplificar e apresentar alguns casos reais que aconteceram em cidades como Nova York, Dubuque, Dubai e Filipinas

\subsubsection{Sem mais buzinas! | Nova York X Trânsito}

Com o intuito de reduzir o tráfego nas principais vias da cidade, o Departamento de Transito de Nova York se rendeu a ajuda da internet das coisas para solucionar esse problema. Por intermédio das câmeras de vídeo, uma tecnologia que já havia sido instalada nas principais avenidas, o departamento de trânsito passou a receber inúmeras fotos durante o dia. Essas fotos, por sua vez, são "transformadas" em dados que mostram como está o trânsito naquele horário, por exemplo. Esses dados foram juntados a outros, como a meteorologia que informa a previsão do tempo e o aplicativo Waze, que é atualizado pelos próprios usuários que informam se houve algum acidente ou qualquer retenção diferente na via. Com a soma dessas informações, o Departamento de Trânsito conseguiu, através de ferramentas como o analytics, compilar e concluir de que forma a chuva atrapalha o fluxo de carros na cidade, ou de que forma um carro quebrado na pista prejudica o trânsito. Mais do que só transformar esses dados em conhecimento, a área conseguiu reduzir o trânsito através de soluções bem simples como alterando o tempo do semáforo, ou enviando informações para as pessoas através do aplicativo caso alguma rua esteja intransitável. Com essa aplicação bem simples de loT, pode-se perceber a enorme capacidade que essa ferramenta tem e pode trazer de benefícios para a sociedade. 


\subsubsection{Pequena enorme cidade | Dubuque X Agua, Luz e Gás}

Apesar de ter apenas 50.000 habitantes, a cidade de Dubuque, localizada em lowa, mostrou como a inovação pode trazer soluções sustentáveis para a região. A ideia inicial tirada de um projeto piloto era conscientizar a população sobre o gasto excessivo com água, gás e luz. O projeto que pode ser visualizado melhor na figura 4, começou em 300 residências e teve como principal mudança a substituição de medidores de água por sensores capazes de fazer a leitura em tempo real do consumo daquela casa. Além disso, esse aparelho divulga essa informação para uma central da prefeitura e para o próprio morador. Esse projeto teve retorno positivo logo no primeiro mês, com uma redução no consumo de $6,6 \%$ e em consequência desse empreendimento, algumas casas ainda conseguiram identificar vazamentos, o que trouxe ainda mais retorno para a cidade. Esse recurso foi ampliado para outros setores como de gás, com 250 exemplos inicialmente e de energia, com mil exemplares.

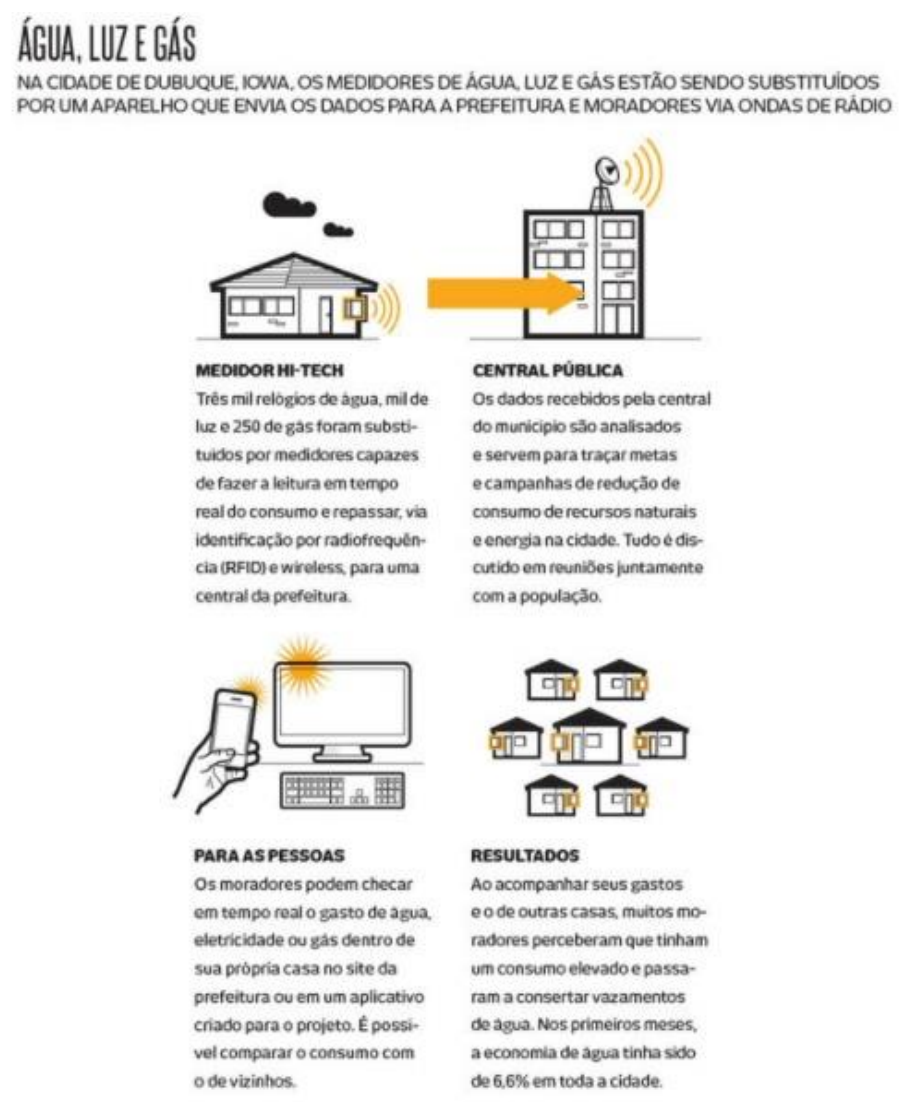

Figura 2 - Sensores para evitar o desperdício 


\subsubsection{Placas Solares | Apple de Dubai}

Por conta das altas temperaturas da cidade de Dubai, a Apple se uniu com a Foster + Partners para criar uma estrutura que amenizasse esse calor durante os dias. A parceria resultou na Solar Wing, uma janela inteligente que se modifica conforme a temperatura do momento. Ou seja, durante o dia, o período mais quente, as janelas se mantêm fechadas para conservar a temperatura da loja, mantendo-a mais fresca e durante a noite, quando a temperatura já está mais baixa, as janelas se abrem. As janelas têm $55 \mathrm{~m}$ de altura e foram feitas com material de polímero com fibra de carbono. Essa janela reduz o gasto com a energia por conta do seu mecanismo que evita gastos como ar condicionado e luz durante o período que não é mais necessário. Na figura 5, pode-se observar os dois momentos da infraestrutura atuando.

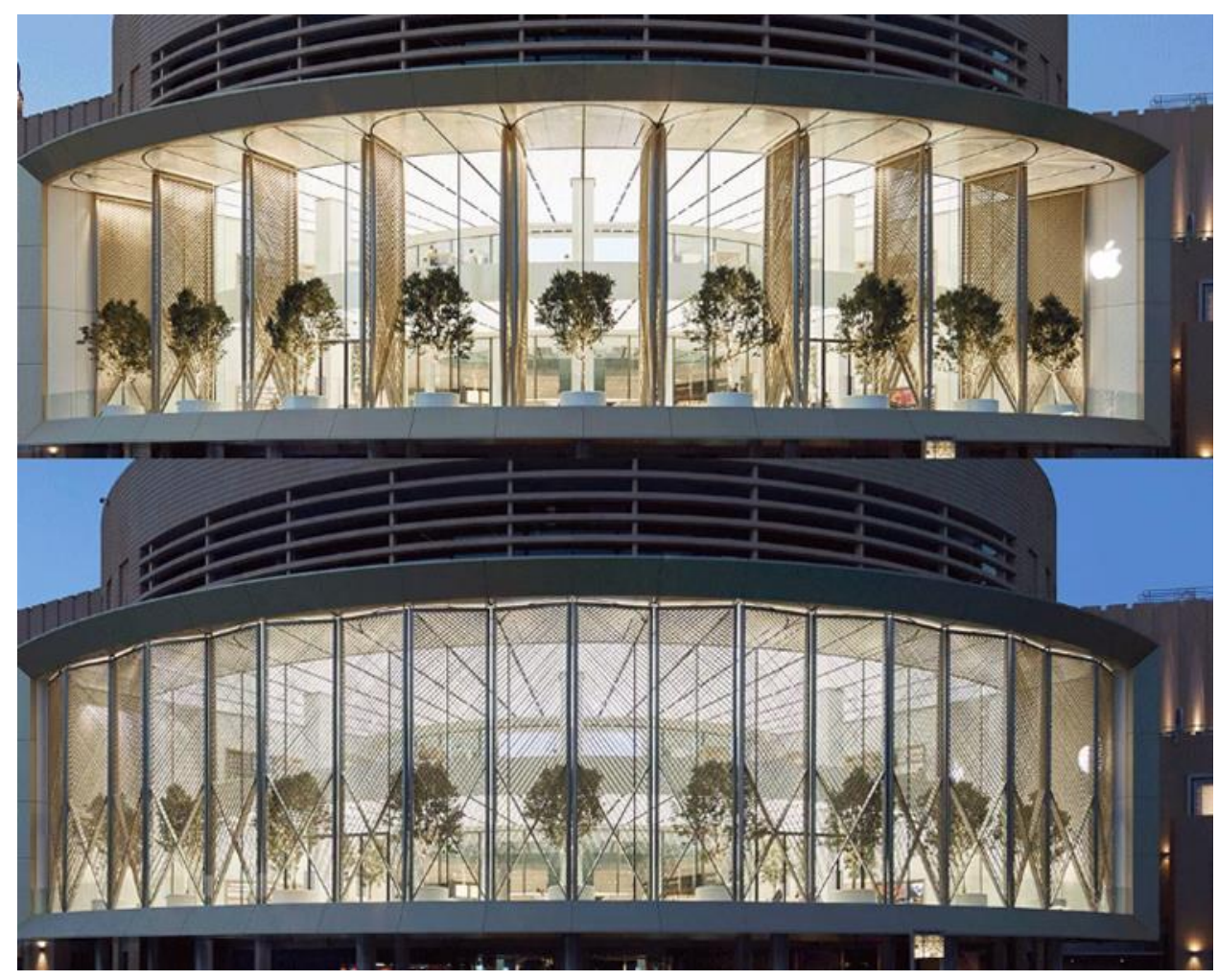

Figura 3 - Placas Solares Ioja Apple

\subsubsection{Unlimited Stadium | Nike Filipinas}

A mais nova pista de corrida da Nike, instalada nas Filipinas, fez muito sucesso entre os habitantes da região. A instalação tem 200 metros de comprimento e é toda revestida por luzes de LED. O grande diferencial dessa 
pista de corrida são os sensores instalados nos tênis dos atletas. Ao completarem a primeira volta, um avatar aparece ao lado dos corredores e começa a competir com cada um. Esse mecanismo funciona da seguinte forma: os dados coletados pelos sensores instalados no tênis informam o tempo de cada competidor e, através desse balanço, o avatar de cada um utiliza sempre o melhor tempo para esforçar o mesmo a ultrapassar o seu próprio recorde. A pista além de ter o formato de uma pegada, possui um limite máximo de até 30 pessoas correndo por vez. A Nike, mais uma vez mostrando que é possível misturar física com tecnologia e inovação.

Certamente, não é uma tarefa fácil se tornar uma cidade inteligente. Contudo, não há dúvidas que o mundo está caminhando para essa direção. Apesar dos diversos exemplos acima abordados, para uma cidade tradicional se transformar em uma cidade inteligente precisa-se de muito mais apoio e investimento, partindo, principalmente, do governo. Uma região que passou por essa transformação e trouxe melhorias para os habitantes foi Barcelona. No início dos anos 2000, O Conselho Municipal da cidade aprovou essa reestruturação em uma área inocupada por conta das fábricas antigas que haviam sido desligadas. A região, também conhecida como 22@ foi redesenhada para ser um bairro verde e sustentável, local para empreender e também um centro de inovação e tecnologia. A ideia surgiu com o intuito de incentivar o comércio criativo na região que por muito tempo foi deixado de lado. Por conta desse trabalho em conjunto, Barcelona ultrapassou Nova York e Londres no quesito smart cities. Essa etapa do trabalho foi destinada para entender melhor como foi o andamento do projeto, os principais stakeholders que influenciaram e o resultado desse investimento.

\subsubsection{Distrito 22@ Barcelona}

Um dos maiores projetos econômicos e empresariais da cidade de Barcelona teve como principal objetivo recuperar a operação produtiva da região e criar um importante polo cientifico, tecnológico e cultural. O distrito 22@Barcelona foi, por muitas décadas, conhecido como o território das indústrias e fábricas. Para limpar essa imagem de local fabril, programa teve como objetivo redefinir três frentes: o meio urbano, a economia local e o ambiente social. Inicialmente, no âmbito urbano o projeto $22 @$ teve a necessidade de criar um ambiente diversificado e equilibrado trazendo diferentes 
instalações, espaços verdes que melhoram a qualidade de vida e de trabalho. Já na reestruturação econômica, o objetivo principal era transformar o distrito em um local de referência para o campo científico, tecnológico e cultural e que, consequentemente, transformou a cidade de Barcelona numa das cidades mais dinâmicas e inovadoras do mundo. Por fim, como projeto social, o 22@ proporcionou a inter-relação entre os diferentes habitantes do distrito, sejam eles profissionais ou moradores da região. A imagem abaixo mostra a divisão do espaço com relação às atividades: a área marcada de vermelho mostra a zona residencial, azul e azul claro os locais destinados às empresas e atividades industriais e verde os espaços públicos.

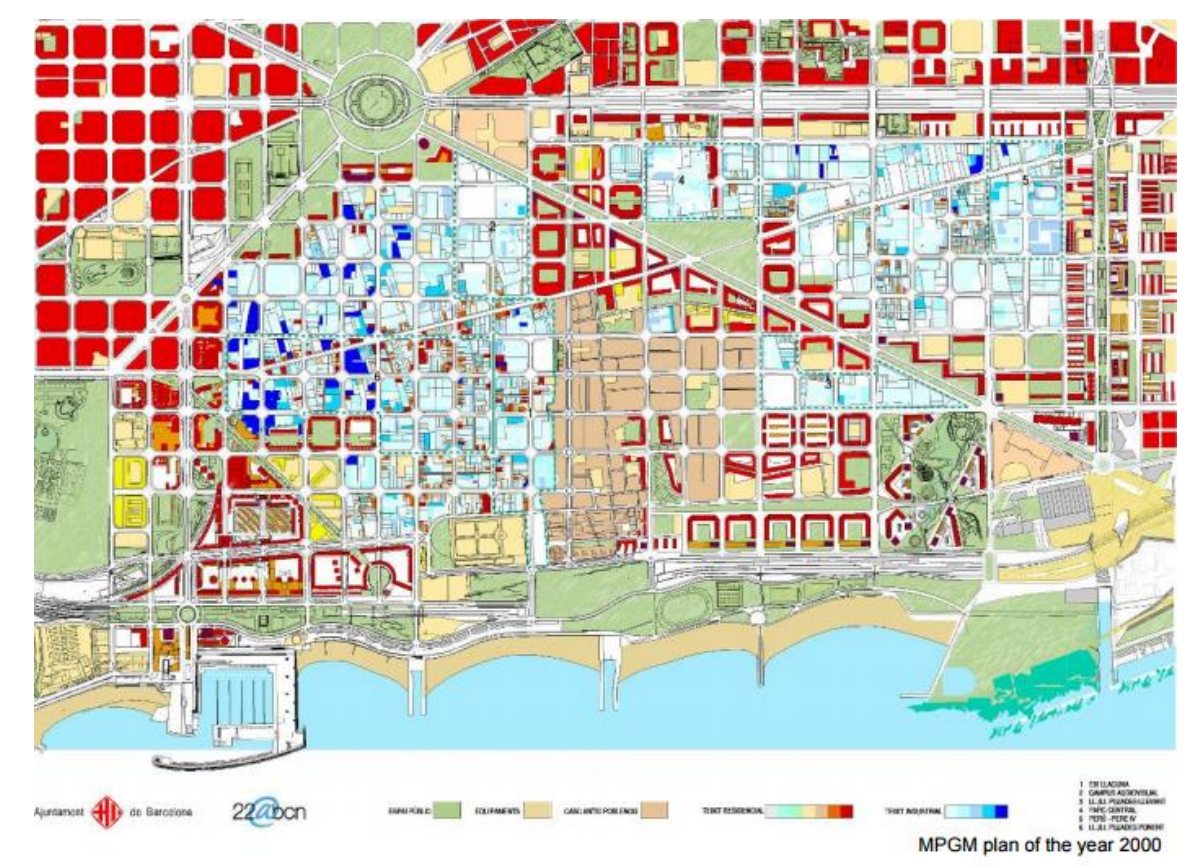

Figura 5 - Distrito 22@ de Barcelona e suas divisões

Fonte: 22barcelona.com

A cadeia de valor do projeto foi montada com a finalidade de trazer para o local quatro fundamentos : o talento - espaço criativo com intuito de atrair e reter pessoas dispostas a se desenvolverem e criarem na região; companhia/empresas: o local tinha que ser um espaço que médias e grandes empresas poderiam se instalar sem aumentar seu custo de produção; inovação: considerada como a mais ambiciosa das ideias, o projeto deveria trazer um ambiente atrativo no qual tenha espaço para a ciência e tecnologia e possa trazer rentabilidade para essas empresas; por fim o urbanismo: diferentemente de todos os trabalhos realizados no passado, a reconstrução do distrito foi 
pensada para trazer novos ambientes verdes sem afetar o espaço e criando novos locais de lazer e urbanismo, tudo construído de forma sustentável.

Com uma duração de oito anos até ser finalizado, a reestruturação do distrito 22@ Barcelona mostra como a cidade foi afeitada por esse projeto. Até 2010 o espaço reservado era de 115 quarteirões o equivalente a 198,26 hectares. O valor desse investimento foi de 180 milhões de euros. Além disso, nesse novo complexo urbano, mais de 1500 empresas foram instaladas e mais de 130.000 empregos foram gerados. Em suma, houveram novas instalações de transporte público como metrô e ônibus, todo o espaço comunitário foi refeito de forma inteligente para os habitantes usufruírem de forma igualitária, como por exemplo ruas sinalizadas, calçadas com rampa para cadeirantes, semáforos com avisos sonoros para pessoas cegas, entre outros artefatos. Ademais, as tubulações de água, óleo e gás foram refeitas toda de forma inteligente, ou seja, evitando total desperdício. Por fim, para agregar ainda mais o projeto, foram feitos espaços reservados para cultura como galerias subterrâneas. A modernização da região foi desenhada para servir de exemplo no quesito serviço de excelência e sustentabilidade. O 22@ possui dez centros de formação superior com mais de cinco mil estudantes, quatro residências para estudantes e pesquisadores, e nove centros de pesquisas. Vale ressaltar a execução desse projeto só foi possível por conta do apoio do governo, em especial, além das empresas e dos centros de pesquisas.

Este trabalho realizado na segunda maior cidade da Espanha foi essencial para mostrar a importância da junção de partes em prol do desenvolvimento da sociedade local. Para se tornar uma cidade inteligente é necessário que todos os campos conversem entre si; em outras palavras, não seria suficiente ter somente empresas na região se não houvesse um local para as pessoas habitarem ou se não houvesse tecnologia ajudando a evoluir. Conforme falado anteriormente, ser uma cidade inteligente não significa apenas utilizar a internet das coisas como ferramenta; significa atingir o equilíbrio no meio urbano, ambiental e fiscal, além de colocar o ser humano no centro de todas as atividades. Exemplos como este da cidade de Barcelona mostram que se tornar uma cidade inteligente necessita de um alinhamento profundo entre os stakeholders. Transformar uma área, um hospital ou até mesmo um bairro em um ambiente conectado exige planejamento para que essa mudança traga todos os benefícios requisitados por todas as partes. 
Mesmo com todo o planejamento e estudo prévio, muitas vezes não é possível resolver todas as questões que impedem o avanço das cidades. Conforme falado anteriormente, o maior desafio das grandes cidades é o crescimento acelerado da população. A partir do momento que a cidade recebe uma quantidade de pessoas maior do que o planejado, as questões básicas que todos os cidadãos têm direito começam a falhar, como por exemplo atendimento público de boa qualidade, um ambiente adequado para se viver, transporte com conforto, um trabalho legal com carteira assinada, entre outras inúmeras questões que não foram pensadas para esse grupo extra. Isto, de certa forma, estimula o crescimento da população nas comunidades e favelas. Apesar de serem um local mais barato de se viver nas grandes metrópoles, as favelas carecem de serviços básicos, como saneamento, abastecimento de água potável, infraestrutura, entre outros. Quando um bairro ou uma região que possui favelas ao seu entorno passa pelo processo de transformação para uma área inteligente, essa região, por sua vez, torna-se mais desejável pela população, como foi o que aconteceu com o distrito 22 de Barcelona anteriormente falado $\mathrm{e}$ como aconteceu com a região do Porto Maravilha que será abordado mais à frente. Como pode-se concluir, com o aumento da procura, esses locais passam por uma reformulação de preços que ocasiona na gentrificação. Para entender melhor como funciona esse processo e quais as causas e consequências dele para a população, o tópico abaixo foi destinado para explica-lo.

\subsection{Gentrificação: causas e consequências}

Segundo a estudiosa Sónia Alves, gentrificação refere-se a reabilitação de habitação urbana deteriorada em bairros operários e a consequente transformação da área num bairro de classe média (Alves, 2015). Em outras palavras, é o fenômeno que ocorre quando um espaço ou bairro passa por alguma transformação no local, como por exemplo a melhora na infraestrutura, valorizando a região e afetando a população de baixa renda local. Esse conceito foi criado em 1964 quando a socióloga Ruth Glass observou a transformação das famílias operárias em famílias de classe média-alta devido a revitalização no centro de um bairro em Londres.

De uma forma mais ampla, gentrificação ocorre quando há uma série de mudanças positivas, ou seja, melhorias físicas ou imateriais, econômicas, sociais e culturais nos centros urbanos antigos que elevam a qualidade de vida, 
realocando a classe média, alta renda para esse local e deslocando os habitantes da classe baixa que viviam anteriormente (Alves, 2015).

Apesar desse conceito existir há mais de cinquenta anos, a gentrificação é algo muito atual, principalmente em países em desenvolvimento como é o caso do Brasil (Silva, 2015). Tem-se visto nas últimas décadas que grupos políticos estão buscando a revitalização nos centros históricos brasileiros, como foi o caso de Maringá, município do Paraná e como é o caso da zona portuária do Rio de Janeiro. Essa revitalização tem como intuito preservar os bens materiais e imateriais dessas áreas consideradas patrimônio histórico e cultural. Para muitos, mas principalmente para o governo, essa reforma traz benefícios para região sendo uma nova fonte de lucro. A área do turismo é a mais beneficiada por inserir esse espaço que anteriormente não era visitado na rota dos turistas, além de, é claro, transformar esse espaço em um novo polo para geração de emprego e renda. Entretanto, por tornar essa região mais atrativa, esse processo incentiva a criação de novos polos o que ocasiona no interesse de classes mais altas na região, provocando, portanto, uma exclusão da população local principalmente por conta da especulação imobiliária. É um processo de fácil entendimento e de difícil resolução: quanto maior a procura, maior o preço a se pagar por aquele serviço ou produto.

Para Neil Smith, geógrafo e acadêmico, o processo de gentrificação é dividido em dois estágios, pelo ponto de vista do morador que está sendo expulso da região. O primeiro diz respeito a valorização do espaço ao redor. Quando um vizinho reforma o apartamento ou a casa, isso valoriza o espaço que ele tem e, automaticamente desvaloriza seu pois o mesmo fica ultrapassado e antigo quando comparado (Silva, 2015). O segundo estágio já diz respeito ao abandono do estabelecimento. Por não conseguir criar um espaço que consiga competir com a vizinhança, o dono do estabelecimento se vê endividado por não conseguir alugar ou vender o espaço o que ocasiona nesse abandono. Esse último estágio, aqui no Brasil, é explicado através do alto valor pago em IPTU. Para alguns é menos custoso abandonar o local do que pagar as dívidas.

Por um lado, é possível enxergar os benefícios desse processo por transformar regiões inabitáveis em novos locais de lazer, trabalho e cultura. Entretanto, nem sempre isso é bem visto pelas pessoas que estavam habitando esse local antes da revitalização. Para evitar que essa situação ocorra, o 
governo da cidade tem que estar preparado para alocar esse grupo de habitantes em outro local. Caso contrário, o ganho com essa revitalização é ínfimo comparado ao gasto que as autoridades terão para manter essas pessoas na cidade.

A cidade do Paraná, Maringá, passou por essa transformação por volta de 1995. Não havia absolutamente nada que fizesse com que Maringá saísse da crise. Nessa época, o prefeito juntamente com outras autoridades se uniram e planejaram o que seria feito para melhorar a região em 20 anos, ou seja, eles se projetaram o que cada prefeito em cada mandato faria, sem saber quem assumiria o cargo. Esse é o grande diferencial de uma cidade que busca resolver o problema e não passá-lo a diante. Atualmente, Maringá é uma das cidades que mais cresce no Brasil (Campos, 2017). Em 2015, enquanto o Brasil teve um crescimento negativo de $3 \%$, Maringá cresceu $14 \%$ segundo 0 presidente do Sinduscon-SF, Mauro Campos. Hoje, Maringá já tem planejamento até para 2045, quando a cidade completa 100 anos. Só o projeto de planejamento custou um investimento de $R \$ 2.000 .000,00$. Esse alto valor significa que todos os stakeholders acreditam que isso, no futuro, trata um resultado positivo para todos, seja empresários, cidadãos ou governo. 0 planejamento evita que problemas como a gentrificação ocorra, pois, com ele é possível traçar todos os possíveis problemas que poderão acontecer no futuro e desenhar soluções para eles.

Não foi diferente com o Porto Maravilha no Estado do Rio de Janeiro. O governo, juntamente com todos os colaboradores que se beneficiaram do projeto como turistas, moradores da região e trabalhadores locais, se uniram em prol da revitalização do Porto Maravilha. Esse trabalho, por sua vez, transformou o bairro do Rio de Janeiro em um dos mais inteligentes, conectados e humanos. A inclusão de uma plataforma tecnológica digital na região fez com que pessoas tivessem uma experiência nunca vista anteriormente. A possibilidade de interagir, trocar e se conectar com uma região fomenta a importância do engajamento dos cidadãos então presentes.

A próxima etapa do trabalho foi destinada para mostrar o início e a causa, ou seja, o motivo que levou o projeto de revitalização do Porto Maravilha ser um case de sucesso. A reestruturação do Porto Maravilha pode ser comparada em uma escala menor com a modernização do Distrito 22@ Barcelona. Em 
comparação, esse projeto foi desenhado para atender a população local habitada, atrair novas empresas para a zona portuária, trazer cultura e ter um espaço criativo disponível na cidade, além de utilizar soluções com aplicações de internet das coisas para reduzir o desperdício e melhorar a segurança. No próximo capítulo será mostrado o contexto por de trás do projeto, ou seja, os problemas que foram apontados pelos colaboradores. 


\section{Projeto Porto Maravilha}

\subsection{Contexto}

Por décadas, a área portuária do Rio de Janeiro foi completamente esquecida pelo Estado, ocasionando um alto nível de pobreza no local, com o mínimo de desenvolvimento. Só foi possível mudar esse cenário em novembro de 2009 quando a lei complementar nº 101 foi aprovada confirmando a revitalização da área portuária e de sua zona de influência. Alguns anos após essa conquista, o Porto Maravilha foi transformado em um exemplo de bairro inteligente e conectado. Essa transformação contou com uma ajuda importantíssima da maior empresa de tecnologia da informação do mundo, a Cisco. A mesma iniciou o seu projeto de renovação que durou cerca de um ano e meio, considerando desde o início da imersão até a entrega final de suas soluções.

Os objetivos desse trabalho eram reintegrar os bairros do Porto Maravilha com o restante da cidade, desenvolver e fortalecer a economia local, melhorar a mobilidade urbana na área, aproveitar o patrimônio histórico e cultural da região e transformar o Porto Maravilha em um dos principais circuitos turísticos da cidade. Segundo o Coordenador de Desenvolvimento Institucional do Parque Tecnológico da UFRJ, Leonardo Melo, o projeto Porto Maravilha foi criado para reaproximar os moradores da região com a população da cidade. Apesar de não ter feito parte do projeto, o coordenador da UFRJ, para um projeto profissional de sua autoria visitou os moradores da região, em especial do morro da Providência antes e depois das obras. Em sua análise, muitos estavam esperançosos com as mudanças, principalmente com relação a segurança e saneamento.

Para alcançar todos esses objetivos, foram necessárias inúmeras entrevistas com trabalhadores locais, moradores da região, turistas, governo e outras entidades. A partir das informações coletadas dos stakeholders, foi iniciado o escopo do projeto com as principais ideias geradas nas pesquisas com base na necessidade dos que mais usufruem a região. A primeira etapa deste 
capítulo mostra os fatores que geraram a urgência para realização dessa mudança.

\subsubsection{Imersão | A real necessidade}

O Rio de Janeiro, como diversas outras cidades do Brasil durante o final do século $X X$, sofreu um processo de favelização por conta da expansão urbana da classe de baixa renda. Além disso, devido a desigualdade social encontrada em todo o país, a capital do Rio sofreu um aumento significativo com relação a violência urbana o que ocasionou um amedrontamento da população e receio de frequentar algumas regiões. Uma dessas regiões era o Porto Maravilha que por mais de décadas, foi considerada uma zona inabitável e perigosa. Entretanto, com o início da pacificação das comunidades somada a autorização da lei permitindo a revitalização do local, o espaço com mais de 5 milhões de metros quadrados que atualmente engloba os bairros de Santo Cristo, Gamboa e Saúde, foi novamente introduzido no mapa da cidade.

O objetivo principal desta restauração é trazer esse espaço histórico que é a zona portuária de volta a atividade de uma forma que esse local possa ser habitado por moradores, ocupado por trabalhadores e, apreciado por toda a sociedade. O mais importante desse trabalho é que ele foi desenhado para as pessoas usufruírem desse espaço urbano sem impactar o meio ambiente. Conforme dito no capítulo anterior, um dos três quesitos para se tornar uma cidade inteligente, é investir na energia limpa sem denegrir o planeta.

Para buscar as melhores soluções para o Projeto de Revitalização do Porto Maravilha, foram necessárias quatro semanas de imersão para entender o que os principais envolvidos gostariam que mudasse em seu cotidiano. Durante esse tempo, foram feitas mais de mil pesquisas com os moradores da região, os trabalhadores locais, os turistas e o governo juntamente com as entidades e todas as questões giravam em torno de quatro frentes: 
1. Desenvolvimento econômico: como atrair grandes empresas para a região (L'Oréal e outras) e novos negócios; como fomentar a economia criativa local; como o SEBRAE pode apoiar os pequenos negócios locais;

2. Espaço residencial: como atrair novos moradores para a região; como alcançar 100.000 habitantes em 10 anos; como melhorar a qualidade de vida dos moradores;

3. Desenvolvimento e infraestrutura: como melhorar a infraestrutura de telecomunicações com a implementação da fibra óptica na região; como melhorar o meio de transporte; como redesenhar as novas ruas da região;

4. Turismo: como reter os turistas recém-chegados de cruzeiros; como explorar o campo cultural para atrair esses turistas.

Com todos esses pontos pré-definidos, a CISCO com apoio do SEBRAE se reuniu para recolher todos os insights dos stakeholders. Para acompanhar a lógica do projeto, este trabalho de conclusão de curso, também, separou o conteúdo coletado através dos grupos de influenciadores.

\subsubsection{Trabalhadores Locais}

Segundo o balanço feito após a junção de todas as pesquisas, foi observado que $71 \%$ das empresas do Porto Maravilha eram microempresas e, somada às pequenas empresas, chega-se a um número de $93 \%$ das empresas da área do porto. Além disso, mais da metade desses empreendimentos (56\%) são do setor de serviço seguido pelo varejo que representa $27 \%$ do negócio local. O terceiro ponto que chamou atenção durante essa etapa do projeto foi que $15 \%$ dos restaurantes e bares da região estão nesse local há mais de 100 anos. Com esses números, pôde-se concluir que a região por ter um alto número de microempresas, possuía, também, uma alta taxa de informalidade e de negócios não registrados. Esse fato trouxe à tona uma oportunidade para o SEBRAE em parceria com a CDURP (Companhia de Desenvolvimento Urbano da Região do Porto) criar um programa de profissionalização para ensinar e capacitar os trabalhadores locais. Vale lembrar que um dos objetivos deste projeto de revitalização do Porto Maravilha era trazer grandes empresas como a 
L'Oréal e o Banco do Brasil para a região para atrair outras instituições. Se, por um lado, esse propósito traz mais desenvolvimento para a área, por outro, os pequenos negócios que são a grande maioria sofrem com o aumento da competitividade e com o aumento de custos.

Durante as entrevistas, foi questionado quais eram os problemas mais críticos da região. Em sua grande maioria, os trabalhadores locais inferiram que a questão da segurança, especulação imobiliária, o transporte e a redução no número de visitantes seriam as principais dificuldades. Apesar da revitalização, a segurança na área ainda não seria algo nem perto do ideal, considerado por muitos um dos principais fatores que afasta os visitantes do local. Por conta da revitalização, os preços dos alugueis subiram mais de $20 \%$. Considerando que a grande maioria dos comerciantes da região são de microempresas, muito provável que poucos conseguirão sobreviver com esse alto custo. O terceiro ponto diz respeito a dificuldade de acessar a área, tanto para os potenciais clientes quanto para os fornecedores. O transporte no Rio de Janeiro sempre foi algo precário, mas os lugares como o do Porto Maravilha, sofrem muito mais por não ser um ponto turístico. Por fim, segundo as pesquisas, muitas empresas estão sendo afetadas não só pela crise no Estado, mas também pela redução do número de turistas na região.

A grande conclusão que pôde-se ter desse cluster foi que as empresas não utilizam as tecnologias adequadas tanto para a época quanto para fins de trabalho; embora a grande maioria concordasse que a segurança é um dos fatores mais precários, todos admitiram que existe uma urgência da inclusão digital, como o Wi-Fi, e que a mesma seria benéfica para os trabalhadores; por fim, segundo os entrevistados, para melhorar a qualidade do serviço da região seria necessário a implementação de novos meios de transportes e um suporte linguístico para auxiliar a comunicação entre comerciantes e turistas estrangeiros.

\subsubsection{Moradores da Região}

Durante as entrevistas com os moradores da região, foi descoberto que $41 \%$ da população local era analfabeta funcional, considerando que dentro da cidade do Rio de Janeiro esse número cai para a metade, 23\%. Além disso, 18\% 
da população da região do Porto Maravilha vive abaixo da linha da pobreza e $10 \%$ encontra-se desempregado. Todos esses números retratam que o abandono da zona portuária fez com que os moradores da região fossem excluídos da sociedade. Durante essa época, o espaço teve pouco ou quase nenhum auxilio para ajudar os habitantes locais com a questão da pobreza e educação. Apesar desse número assustador, o projeto de revitalização proporcionou a alguns moradores uma nova chance: os mesmos foram treinados para serem inseridos no mercado de trabalho local novamente. Isso trouxe um ar de esperança entre essas pessoas. Em sua grande maioria, os moradores locais conseguem ver melhoria na região em comparação como era no passado, principalmente com relação a infraestrutura de telecomunicação. Em contrapartida, uma parte dos entrevistados acredita que todas essas propostas estão sendo feitas apenas para os turistas e não para os moradores da região.

Os pontos mais cruciais destacados pelos moradores foram o transporte, a segurança, a falta de saneamento básico e sistema elétrico. A primeira crítica a ser feita com relação aos tópicos acima citados é que todos essas questões graves são direitos básicos que todos os moradores independentemente da realização do projeto deveriam ter. Analisando caso a caso, com relação ao transporte, diferentemente do que foi abordado pelos trabalhadores da região, as obras afetam diretamente a locomoção dos moradores para os seus trabalhos. Com relação à segurança, os moradores acreditam que, com o aumento do número de turistas na região, aumentará, também o número de assaltos e criminalidade e isso causa angustia e medo entre esse cluster. Além desses pontos, a ineficiência da coleta de lixo somada ao alto número de obras na região causou um aumento considerável na quantidade de lixo na rua. Por fim, todos concordam que o sistema de luz utilizado na zona portuária não é suficiente para a região.

De certa forma a maioria dos habitantes concordaram que a implementação da tecnologia na área é fundamental, mas que se ela não trouxer um propósito para todos, não somente para os habitantes, ela não será utilizada. Ou seja, em outras palavras, se essa tecnologia não está conectada com a realidade do público ela será rapidamente esquecida e vandalizada. À vista disso, toda essa inovação seria feita para ajudar os moradores a superarem os problemas de infraestrutura, telecomunicação e transporte. 


\subsubsection{Turistas}

O Rio de Janeiro após sua série de eventos esportivos como a Copa das Confederações em 2013, a Copa do Mundo em 2014 e as Olimpíadas em 2016, se tornou a cidade mais atrativa para turistas do Brasil no ano passado, segundo a Revista Exame. Durante as Olimpíadas, o Rio recebeu 1,2 milhões de turistas em um mês de evento. Apesar desse número mostrar o sucesso desse espetáculo, segundo os próprios visitantes, ainda falta muito para essa cidade se tornar Maravilhosa.

Segundo os próprios turistas, os pontos mais críticos que os fizeram repensar antes de indicar o Rio de Janeiro para outras pessoas foram a disponibilidade de informação, a comunicação e os negócios informais que acontecem na região. Para eles, a falta de informação a respeito do local juntamente com a história por trás do Porto Maravilha causa uma má impressão e mostra a falta de preocupação com a região. Outro ponto levantado foi com relação a língua e a falta de profissionais que pudessem ajudar os visitantes. Os mesmos relataram que tiveram problemas para encontrar pessoas que falassem outra língua, como o inglês ou até espanhol. Por fim, o terceiro ponto apresentado pelos convidados foi que a região do Porto tem pouca variedade $e$ qualidade de lojas e restaurantes e esse fato dificulta a manter os turistas na região e atrair novos a irem conhecer o local.

Em comparação com os outros pontos turísticos como o Pão de Açúcar e o Cristo Redentor, o Porto Maravilha perde em número com relação a tecnologia e infraestrutura. Todos os entrevistados levantaram esse ponto sobre a falta de inovação no local, principalmente nos negócios locais e restaurantes. Nesse cluster, o principal desafio encontrado foi reter os turistas que chegam de cruzeiro e não se hospedam pela região e até mesmo nem conhecem o Porto. A solução que os turistas acreditam ser crucial para esse desafio é a implementação de tecnologia na região.

\subsubsection{Governo e outras Empresas}

Para esse conjunto, a importância da revitalização do Porto Maravilha está além de incluir tecnologia no local. A reconstrução dessa região tanto para o governo quanto para empresas envolvidas traria um novo comércio e uma nova fonte de receita que antes não era nem cogitada por conta da carência do local. 
Segundo o governo e as entidades entrevistadas, os pontos mais importantes e que afetam a região são a exclusão social, a falta de infraestrutura no local e a falta de capacidade de mudança. Para eles, a principal preocupação e que deve ser, consequentemente a primeira transformação é a inclusão daqueles mais humildes e miseráveis na sociedade. Além disso, como levantado em todos os outros grupos de pesquisa, a ausência de tecnologia primária no local como a internet afeta diretamente os moradores e trabalhadores da região, como também os turistas. Por fim, o governo junto com os empresários acreditam que essa revitalização será difícil visto que os moradores encontramse resistente com essa transição que acontece no Porto Maravilha.

Embora muitos dos entrevistados levantarem soluções diferentes para esses três problemas principais, no geral a maioria concordou que o investimento em tecnologia na região seria mais relevante para os moradores, seguido das empresas locais e dos turistas. Esse grupo de entrevistados corroborou com todas as ideias apontadas pelos outros clusters de que o Porto Maravilha precisa ser desenhado para estar conectado com o público e trazer novas soluções inovadoras para a região.

Após a análise das entrevistas de todos os grupos, a CISCO juntamente com o SEBRAE concluiu que a principal mudança que afetaria todos os stakeholders seria a inclusão da tecnologia no local. Com a implementação dessa plataforma, o governo estaria conectado com o público, com os turistas e com os trabalhadores locais e, dessa forma, criaria uma relação entre essas pessoas, além de melhorar a operação urbana na região (com a tecnologia é possível solucionar os problemas locais com mais agilidade).

O próximo capítulo foi separado para apresentar todas as propostas de melhoria que foram levantadas por esses grupos e as que foram implementadas de fato no Porto Maravilha, além de apresentar o ponto de vista dos principais beneficiados com a realização do projeto. 


\section{Propostas de Melhoria | Projeto Porto Maravilha}

Dentre todas as soluções propostas durante as entrevistas dos trabalhadores, turistas, moradores e entidades, a implementação de WI-FI seria a principal delas. A inclusão da internet ajudaria os residentes e os visitantes a terem uma melhor experiência no Porto Maravilha. A ideia principal dos turistas foi a criação de um aplicativo que mostrasse todas as informações do porto incluindo as atrações principais, uma breve apresentação sobre a história da zona portuária, uma ferramenta que os ajudassem a se locomover na região e auxiliá-los a entender a língua local seria ideal para eles se ambientarem com o espaço. Já para o governo e entidades, a ideia proposta foi a criação de um aplicativo que monitorasse a performance das residências e das empresas com relação ao consumo de energia, que informasse para as pessoas quais redes hospitalares, restaurantes e hotéis estão próximos à região, que tivesse um tradutor simultâneo e uma tecnologia que apoiasse a educação com realidade aumentada. Diferentemente dos dois grupos acima, os residentes não solucionaram suas questões com a ideia de um aplicativo. Para eles, a importância de um sistema inteligente de monitoramento com câmeras de segurança era o essencial para a região. Por fim, todas as ideias propostas pelos outros grupos foram levantadas pelos trabalhadores locais, desde a criação de um aplicativo que auxiliasse os turistas até o monitoramento da região por câmeras.

Após o processo de imersão com os colaboradores e principais envolvidos com o projeto, chegou o momento de ideação de todas as percepções levantadas por eles. Para chegar na melhor solução, a CISCO se uniu com a consultoria Frost \& Sullivan que foi convidada para ministrar 0 workshop de prototipação. O campo que recebeu maior número de ideias foi a cidade por abranger os dois públicos mais importantes para o projeto: moradores e trabalhadores locais. Em contrapartida, o tema que recebeu menos contribuição foi tecnologia por esse item já estar incorporado em todos os outros tópicos. 
Para o sucesso do projeto, no final, foram implementadas quinze soluções inovadores na região que transformaram o Porto Maravilha em um "laboratório urbano vivo", segundo a CISCO. Com essas soluções, foi possível atrair novas empresas e starups para a região, permitir que os cidadãos se conectem e interajam com a plataforma e melhorar a qualidade de vida da população local. Dentre as quinze soluções, abaixo foram listadas as sete mais importantes segundo os stakeholders:

- Implementação de 100 mil metros quadrados da rede Wi-Fi gratuita: através dessa tecnologia, todo o público pode se conectar e interagir, basta ter um celular. Essa solução trouxe benefícios para todos os grupos.

- Instalação de quatro quiosques interativos que informam para os visitantes a localização das principais atrações, agenda cultural, serviços públicos, entre outras funcionalidades. Essa plataforma inteligente proporciona para os cidadãos uma maior conectividade através do "felicitômetro" onde os mesmos conseguem interagir opinando, em tempo real, qual local preferiram, qual está mais cheio, etc. Todas essas informações aparecem no quiosque.

- $\quad$ Criação do Guia do Porto: essa plataforma mostra todas as rotas disponíveis na região e auxilia os turistas e se localizarem e se ambientarem. Além disso, foi criado um outro guia chamado "guia inteligente" onde os usuários também podem incluir seus roteiros pelo Porto Maravilha e ajudar os visitantes a conhecer os melhores locais do porto.

- Instalação do posto de atendimento "Rio City Info": com apoio da RIOTUR, esses postos são conectados diretamente com uma central de atendimento que informa para os visitantes dicas e sugestões e esclarece as dúvidas dos mesmos. Para agregar ainda mais, o público consegue escolher o idioma e a interação ocorre com um comando de voz e vídeo, como se a pessoa estivesse conversando presencialmente com um atendente.

- $\quad$ Sete estações com sensores foram instaladas para monitorar, em tempo real, o meio ambiente da região. Um desses sensores foi instalado nos bueiros do Porto, conforme mostra a figura 5 . Ele informa para uma central o exato momento que a sujeira ultrapassa o limite do coletor. Com esse 
mecanismo, não há chances de ter alagamento na área. Vale ressaltar que todos esses sensores são alimentados por energia solar.

- Criação do Museu do Amanhã. Diferente de todos os outros museus da cidade, o museu do amanhã promove uma experiência com a sociedade que engloba a sustentabilidade, cultura, ciência e tecnologia e arte.

- Implementação do VLT (Veículo Leve sobre Trilhos): o VLT, projeto da prefeitura do Rio de Janeiro, foi criado para conectar o centro da cidade com o Porto Maravilha. É possível se deslocar do Aeroporto do Santos Dumont até a Rodoviária.

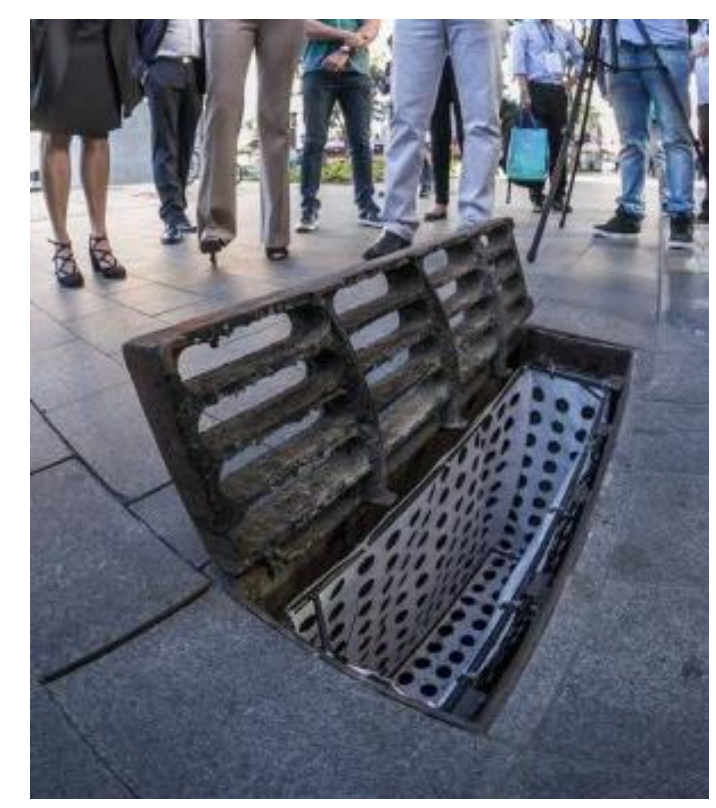

Figura 6 - Bueiros com sensores no Porto Maravilha

Fonte: O Globo

Com todas essas implementações, o Rio de Janeiro deu mais um passo para se tornar uma cidade inteligente e conectada. Todavia, sabe-se que essas mudanças não são suficientes para o Rio de Janeiro se tornar uma smart city. Apesar da força deste projeto na região, alguns pontos que foram levantados na imersão não foram solucionados: pela perspectiva dos moradores o projeto deu errado por não trazerem as melhorias esperadas. Além disso, em uma entrevista com Leonardo Melo, pesquisador do Programa de Políticas Públicas, Estratégias e Desenvolvimento do Instituto de Economia da UFRJ, ele levantou que o Morro 
da Providência sofreu com a remoção da única praça pública que havia na região para implementar um teleférico que foi criado para atrair turistas para a região. Outra perspectiva que não foi alcançada segundo o pesquisador foi a moradia. O Plano de Habilitação de Interesse Social não foi colocado em prática de forma a modificar o cenário atual. Neste plano o principal objetivo é integrar as políticas habitacionais federais com as demais políticas setoriais de desenvolvimento urbano, ambiental e inclusão social. (2011, PLANO LOCAL DE HABITAÇÃO DE INTERESSE SOCIAL). De fato, esses interesses não foram modificados após a aplicação deste projeto, ou seja, os moradores da região continuam sofrendo com o descaso do governo. Em contrapartida, um ponto que obteve sucesso foi a reformulação urbanística. Após o projeto, a região se tornou mais agradável para se habitar, deixando aquele cenário de região inocupada para trás. Ademais, a inclusão de museus na região foi também uma questão positiva principalmente por atrair o público a visitar e conhecer a região, além de trazer de volta a cultura e história para a zona portuária. Outro ponto que agregou muito no projeto foram as ferramentas instaladas na região. Essas, por sua vez, fornecem dados para um central que analisa todas as informações compiladas nesses dispositivos. Com esse mecanismo é possível ter um controle maior sobre o fluxo de pessoas e as tendências que acontecem no local. Dessa forma, cria-se um ciclo de ideias, onde esses dados informam novas tendências e essas tendências criam novas soluções.

Para entender melhor todas as questões levantadas no projeto, abaixo serão relatadas opiniões de pessoas que foram envolvidas de certa forma com a revitalização do Porto Maravilha. Dentre elas, estão os turistas, moradores da região e trabalhadores da região. Infelizmente, não foi possível entrevistar as empresas e entidades que realizaram o projeto pela falta de abertura das mesmas.

\subsection{Trabalhadores locais}

Nesse cluster, dois gerentes de dois restaurantes da região foram entrevistados. O Anderson, que está no restaurante $A$ há 2 anos, e a Rosângela, que está há 11 anos no restaurante $B$.

Por ser mais afastado do Porto Maravilha, o restaurante A sofreu mais com a revitalização na zona portuária. Segundo Anderson, desde setembro de 2016 que o estabelecimento sofre com a queda do público. Em média, no período das 
Olimpíadas, o restaurante recebia 800 pessoas por dia. Atualmente, durante a semana esse número não passa de 100 pessoas. Para competir com os outros estabelecimentos da região, o Anderson teve que diminuir os preços dos pratos e trocar de fornecedor por um período, pois, o mesmo havia aumentado o preço. Entretanto, não foi possível manter esse plano por muito tempo e o restaurante teve que retornar com o valor inicial. Todavia, um ponto positivo que o gerente do restaurante A levantou durante a entrevista foi a implementação do Centro Presente na região. Com os guardas na região, hoje em dia, é possível caminhar pelo porto sem se preocupar em ser assaltado ou furtado. Antes dessa revitalização, os roubos na região aconteciam com frequência. Por fim, para o Anderson, a revitalização trouxe melhorias como a questão da segurança mas em contrapartida ele acredita que o governo deve investir em mais eventos na região para atrair de novo o público.

Diferentemente do restaurante A, o restaurante B conta com um posicionamento melhor, localizado bem em frente ao Porto Maravilha. Segundo Rosangela, o projeto de revitalização do porto só trouxe benefícios. Segundo ela, o grande diferencial do projeto foi a questão da segurança. Antigamente, as pessoas não cogitavam em passear pelo local devido a insegurança. Hoje em dia isso já não acontece por causa do Centro Presente. Por ser localizado em uma área com mais movimento, o restaurante B faz parceria com caravanas de viagem e empresas que reservam o local para almoçar. Ou seja, a questão da falta de clientes não foi um problema mencionado pela Rosangela, visto que a mesma se planeja para atrair novos clientes.

Em suma, ambos gerentes relataram que a questão da segurança na região foi melhorada e acreditam que é o ponto mais vantajoso criado com a revitalização. Entretanto a falta de planejamento do governo com relação a programação na região faz com que estabelecimentos, como é o caso do restaurante $\mathrm{A}$, sofram com a falta de público no período da semana e até mesmo final de semana.

\subsection{Moradores locais}

Em uma entrevista com Lucia, que mora no Morro da Previdência desde 2008, foi possível entender o ponto de vista dos moradores locais. Segundo ela, a região da Praça Mauá teve uma melhora de 100\% desde que foi implementado esse projeto de revitalização. Hoje em dia, a Lucia é camelô e vende seus produtos em frente ao Museu do Amanhã. Antes da reforma, ela trabalhava na 
Cinelândia que também é uma área de risco, entretanto tinha mais movimentação que a Praça Mauá. Com a revitalização, as áreas próximas também foram reformadas, como aconteceu no local onde ela mora. As ruas foram calçadas, colocaram corrimão da escadaria que dá acesso ao Morro da Previdência, incluíram o saneamento básico de esgoto e água na região entre outros inúmeros benefícios implementados. Questionada a respeito do aumento do valor do local, Lucia informou que não sofreu muito com essa questão por já ter uma casa própria e não ter que pagar aluguel. Entretanto, a mesma relatou um caso ocorrido com a sua vizinha que teve que se mudar neste ano por conta do aumento do custo de vida na região. Até o momento a casa onde a mesma morava não foi alugada e está vazia desde março. Além das questões acima abordadas, Lucia informou que o movimento no morro aumentou após a implementação dos hostels e isso fez com que turistas começassem a conhecer o Morro da Previdência.

Conforme falado no início do trabalho, a questão levantada por Lucia a respeito de sua vizinha mostra que a gentrificação também ocorreu na região do Porto Maravilha. Segundo a mesma, a região agora está mais habitável e isso traz novos públicos como os turistas, por exemplo. Esse fato implica em querer melhorar as moradias no local, realizando reformas nos apartamentos e casas o que ocasiona no aumento dos preços dos alugueis na região. Para ela, a questão da segurança foi bem realizada e trouxe benefícios não só para os moradores da região como também para todos os colaboradores como trabalhadores e turistas.

\subsection{Turistas}

Em uma rápida conversa com Laís, foi possível entender o que motiva os turistas brasileiros a visitarem o Rio de Janeiro, em especial o Porto Maravilha. Laís mora em Natal, tem 25 anos mas desde pequena vem ao Rio de Janeiro visitar seus tios ao menos uma vez ao ano. A sua primeira visita no Porto Maravilha foi no período das Olimpíadas no ano passado e desde então, já veio ao Rio três vezes depois e as três ela foi na área portuária. Segundo ela, o Porto Maravilha tornou-se o ponto turístico preferido dela por ter uma enorme gama de opções para se fazer. Para ela, a região tornou-se um local de aprendizado onde é possível interagir com o ambiente, além de visitar os museus e conhecer a história antiga da zona portuária. 
Em outras palavras, o projeto de revitalização do Porto Maravilha pelo olhar de um turista foi um dos projetos mais bem executados já feitos no Rio de Janeiro. As soluções implementadas resolveram todas as questões que foram anteriormente questionadas por esse grupo de influenciadores.

Para concluir, com essas entrevistas foi possível enxergar os dois lados desse projeto. $O$ positivo que criou-se um novo ambiente propício para visitação e habitação do público que antes não era cogitado como uma região turística. Além disso, a questão da segurança que foi solucionada com a implementação do Centro Presente e trouxe benefícios não só para os turistas como também para os moradores da região e os trabalhadores locais. Entretanto, a falta de planejamento por parte das autoridades causa problemas como diminuição dos visitantes durante o período que não há eventos na região. Para os trabalhadores locais esse fato prejudica muito o seu trabalho, principalmente durante a semana. Além disso, com a revitalização da região e da área ao entorno, os preços aumentaram devido ao aumento da procura e valorização da região ocasionando no fenômeno da gentrificação. Esse fato, por sua vez, ocorre por causa da falta de planejamento por parte do governo que mostra o descaso com a população local. 


\section{Conclusão}

O desenvolvimento do presente trabalho mostrou a importância do surgimento das Cidades Inteligentes ao redor do mundo. Nesse estudo de caso, foi possível analisar os diversos benefícios que essa nova tendência traz, como ter soluções inovadoras sem denegrir o meio ambiente, racionalizar processos, melhorar a segurança nos locais, agilizar o atendimento nos hospitais e até mesmo fazê-los de forma remota entre outros diversos privilégios. O grande diferencial das cidades inteligentes está em criar um planejamento a longe prazo onde o cidadão é o maior beneficiado com esse projeto.

Dada a relevância deste tema, pode-se concluir que cidades inteligentes são o futuro próximo das cidades tradicionais. A maior vantagem de ter uma cidade inteligente é que a área, como um todo, se comunica, desde a gestão pública até a infraestrutura dos apartamentos e casas. As questões que são solucionadas para acontecer a transformação de cidade tradicional para cidade inteligente são os aspectos humanos, sociais e ambientais dos centros urbanos a fim de melhorar a vida da população.

Por um lado, essa nova tendência mostra como será o futuro das cidades onde o ambiente busca soluções sustentáveis para diminuir o desperdício e aumentar a produtividade e qualidade de vida da região. Entretanto, se não há planejamento a longo prazo por parte do governo, enxergando a necessidade de todos os habitantes da região, sejam eles da classe $A$ ou $D$, essa transformação nunca acontecerá de forma completa. Para se ter uma cidade inteligente, o cidadão tem que estar integrado com o poder público.

Ao analisar o Projeto do Porto Maravilha pode-se observar as melhorias que foram trazidas com as soluções feitas na zona portuária. De uma região completamente devastada, o Porto Maravilha tornou-se um polo conectado, inteligente e humano onde as pessoas podem interagir com o meio ambiente. Do ponto de vista urbano e turístico, o projeto Porto Maravilha conseguiu completar seus objetivos por transformar o local em um lugar mais urbano e mais habitável, além de incluir a cultura da cidade com os grandes museus expostos na região. 
Apesar de todo sucesso do trabalho, foi possível enxergar falhas na execução do projeto, principalmente com aqueles que deveriam ter sido os mais beneficiados com a revitalização: os moradores e trabalhadores locais. Além deles terem sofrido com o aumento dos preços no local, a precariedade do serviço na região continuou escassa. Além disso, a falta de planejamento causa, também, uma dependência dos trabalhadores da região com os eventos turísticos. Quando os mesmos não acontecem, os trabalhadores locais sofrem por não conseguirem alcançar um número mínimo de vendas no período. Dessa forma é possível concluir que, mesmo com o avanço da cidade do Rio de Janeiro com relação a infraestrutura e tecnologia, ainda faltam inúmeros obstáculos para a mesma se tornar uma, então, cidade inteligente.

A grande questão que deve ser levantada em qualquer projeto feito para transformar uma cidade é o planejamento. Sem planejamento por parte das autoridades, não há um controle dos gastos, e a cidade acaba não recebendo o investimento planejado para melhorar a qualidade de vida da população. $O$ investimento que deveria ser utilizado para melhorar a saúde pública ou o meio de transporte, por exemplo, é esquecido e transferido para outras questões que não afetam diretamente a população.

É possível enxergar os benefícios desse processo de revitalização de regiões inabitáveis em novos locais de lazer, trabalho e cultura. Entretanto, nem sempre isso é bem visto pelas pessoas que estavam habitando esse local antes da revitalização. Para evitar que essa situação ocorra, o governo da cidade tem que estar preparado para alocar esse grupo de habitantes em outro local. Caso contrário, o ganho com essa revitalização é ínfimo comparado ao gasto que as autoridades terão para manter essas pessoas na cidade.

Por fim, esse trabalho atingiu o seu objetivo por apresentar através da análise do projeto feito no Porto Maravilha quais as vantagens e desvantagens de transformar uma região em um local mais prazeroso de se habitar. Com isso, foi possível entender os dois lados dessa nova tendência mundial que são as cidades inteligentes. 


\section{Referências Bibliográficas}

ALVES, S. Requalificação e Gentrificação no Centro Histórico do Porto. 2016 Disponível em: < ICS_SAlves_Requalificacao_ARI.pdf> Acesso em: $02 / 07 / 2017$

ASHTON, K. That "Internet of Things" Thing. RFID JOURNAL, 22 de junho de 2009. Disponível em: <http://www.itrco.jp/libraries/RFIDjournalThat\%20Internet\%20of\%20Things\%20Thing.pdf>. Acesso: 18/04/2017

Arraes, J ; Silva A. Porto Maravilha: Permanências e Mudanças. Porto Maravilha, 01 de outubro de 2014. Disponível em:<http://www.portomaravilha.com.br/noticiasdetalhe/4268 $>$. Acesso: 25 de maio de 2017

Avenues The World School. Disponível em: <http://www.avenues.org/> Acesso: 12 de abril de 2017

Azevedo, L ; Faulhaber, L. SMH 2016: Remoções no Rio de Janeiro Olímpico. Heinrich Böll Stiftung Brasil, 5 de agosto de 2015. Disponível em: $<$ ttps://br.boell.org/pt-br/2015/08/05/smh-2016-remocoes-no-rio-de-janeiroolimpico>. Acesso em: 18/04/2017

BAIMA, C. POPULAÇÃO URBANA GLOBAL PASSOU DE 38\% A 55\% DO TOTAL EM 40 ANOS. O GLOBO, 20 de outubro de 2016. Disponível em: <https://oglobo.globo.com/sociedade/populacao-urbana-global-passou-de-38-55do-total-em-40-anos-20319443>. Acesso em: 03/07/2017

BELISÁRIO, A. A outra história do Porto Maravilha, 2016

BNDES, Chamada Pública de Seleção de Estudo Técnico para Diagnóstico e Proposição de Políticas Públicas no Tema Internet das Coisas, 2016 
BOUSKELA, M.; CASSEB, M. BASSI, S.; LUCA, C.; FACCHINA, M. Caminho para as Smart Cities: Da Gestão Tradicional para a Cidade Inteligente., 2016.

Borja, R. ; Gama, K. Middleware para Cidades Inteligentes baseado em um Barramento de Serviços. Universidade Federal de Pernambuco (UFPE), 2014. Disponível em: <http://www.lbd.dcc.ufmg.br/colecoes/sbsi/2014/0050.pdf>. Acesso: $14 / 05 / 2017$

CISCO, Cisco e Prefeitura do RJ transformam Porto Maravilha em exemplo de bairro mais conectado, inteligente e humano, 2016

CISCO, Cisco fornece tecnologia de telemedicina para Hospital Albert Einstein, 2013

CISCO, Comunidades Digitais e a Internet de Todas as Coisas, 2015.

CISCO: Internet das Coisas (IoT). Disponível em: <http://www.cisco.com/c/pt br/solutions/internet-of-things/overview.html> Acesso em 20 de maio de 2017

CISCO. Transformando o Brasil em um país digital. Disponível em:<http://www.cisco.com/c/m/pt br/never-better/core-networking.html> Acesso: 02 de maio 2017

COHEN, B. The top 10 Smart Cities on the planet. CO. Design, 01 de novembro de 2012. Disponível em: <https://www.fastcodesign.com/1679127/thetop-10-smart-cities-on-the-planet>. Acesso: 18/04/2017

DINO. Estatísticas de uso de celular no Brasil. EXAME, 22 de abril de 2016. Disponível em: <http://exame.abril.com.br/negocios/dino/estatisticas-de-uso-decelular-no-brasil- dino89091436131/>. Acesso em: 01/07/2017

EVANS, D. A internet das Coisas: Como a próxima evolução da internet está mudando tudo. 2013

Falcão, R. G. A ; Baptista, S. C ; Menezes , C. L. Crowd4City: Utilizando Sensores Humanos como Fonte de Dados em Cidades Inteligentes. VIII 
Simpósio Brasileiro de Sistemas de Informação, 2012. Disponível em: <http://www.lbd.dcc.ufmg.br/colecoes/sbsi/2012/0017.pdf >. Acesso: 01/07/2017

FGV PROJETOS. O que é uma cidade inteligente? FGV PROJETOS, n.d. Disponível em: <http://fgvprojetos.fgv.br/noticias/o-que-e-uma-cidadeinteligente>. Acesso: 30/06/2017

FURTADO, C. Intervenção do Estado e (re)estruturação urbana. Um estudo sobre gentrificação, 2014. Disponível em:< 2236-9996-cm-16-32-0341.pdf> Acesso em: 02/07/2017

GAMA, K ; Alvaro, A ; Peixoto, E. Em Direção a um Modelo de Maturidade Tecnológica para Cidades Inteligentes. VIII Simpósio Brasileiro de Sistemas de Informação, 2012. Disponível em: <http://www.lbd.dcc.ufmg.br/colecoes/sbsi/2012/0018.pdf>. Acesso: 29/06/2017.

Globo, Escola dos EUA investe em tecnologia para a educação dos alunos. Disponível em: <https://globoplay.globo.com/v/2488843/> Acesso: 12 de abril de 2017

GRIS, R. Maringá está entre as $\mathbf{2 0}$ cidades brasileiras mais inteligentes e agradáveis de viver. O Diário, 16 de junho de 2016. Disponível em: <http://maringa.odiario.com/maringa/2016/06/maringa-esta-entre-as-20-cidadesbrasileiras-mais-inteligentes-e-agradaveis-de-viver/2177820/>. Acesso: $18 / 04 / 2017$

IPv6. Disponível em:<http://ipv6.br/> Acesso: 09 de abril de 2017

LEMOS, A. Cidades inteligentes. GVexecutivo, dezembro de 2013. Disponível em:

< http://bibliotecadigital.fgv.br/ojs/index.php/gvexecutivo/article/view/20720/19454 >. Acesso: 29/06/2017.

MITCHELL, S. VILLA, N.; STEWART-WEEKS, M.; LANGE, A. The Internet of Everthing for Cities, 2013.

Porto Maravilha: Permanências e Mudanças. Disponível em:<http://www.portomaravilha.com.br/noticiasdetalhe/4268> Acesso: 25 de maio de 2017 
REINA, M.; COMARÚ, F. Dinâmicas imobiliárias e políticas urbanas no centro de São Paulo: uma discussão sobre gentrificação na Mooca, 2015. Disponível em: < 2236-9996-cm-17-34-0419.pdf> Acesso em: 03/07/2017

Revista Galileu: Cidades Inteligentes. Disponível em: <http://revistagalileu.globo.com/Revista/Common/0,ERT338454-17773,00.html> Acesso: 23 de maio 2017

RIUS, R.; TOMÁS, A.; CORDUENTE, A. BLANCAFORT, A. 22@Barcelona, the innovation district, 2007.

ROSA, J. Plano de Local de Habilitação de Interesse Social, 2011

SANTOS, R. Tendência Mundial: A internet das Coisas Aplicada à educação. 2010

SANTOS, F. Startupi: Parceria entre Cisco e Prefeitura do Rio de Janeiro transformam o Porto Maravilha em bairro mais conectado. Disponível em:<https://startupi.com.br/2016/07/parceria-entre-cisco-e-prefeitura-do-rio-dejaneiro-transformam-o-porto-maravilha-em-bairro-mais-conectado/> Acesso: 30 de abril de 2017

SEAR, R.; FARIA, J.; JANUARIO, I.Assessment Porto Maravilha Cisco, 2016

SILVA, J.; PEIXOTO, R.; Gentrificação e resistência popular nas feiras e portos públicos da Estrada Nova em Belém (PA), 2015. Disponível em: < 1981-8122-bgoeldi-10-3-0681.pdf> Acesso em: 01/07/2017

SILVA, G.; FERETTI, S.; SETTE, E. GENTRIFICAÇÃO E POLÍTICAS DE RDO. Revolução Digital: o computador pessoal, a internet e os dispositivos móveis. Revista Digital online, 2015. Disponível em: $<$ http://www.revistadigitalonline.com.br/revistadigital/revolucao-digital-ocomputador-pessoal-a-internet-e-os-dispositivos-moveis/>. Acesso: 14/05/2017

SMITH, N. De volta a cidade: dos processos de gentrificação às políticas de revitalização dos centros urbanos, 2003 Disponível em: https://books.google.com.br/books?hl=ptBR\&lr=\&id=3H5bhgirfvcC\&oi=fnd\&pg=PA59\&dq=gentrifica\%C3\%A7\%C3\%A3o\& ots=azFAtZ9UMC\&sig=JYtSe JS7pDczFcqH6Z1 K8sDvj4\#v=onepage\&q=gentrifi 
ca\%C3\%A7\%C3\%A3o\&f=false $>$ Acesso em: 03/07/2017

REVITALIZAÇÃO NOS CENTROS HISTÓRICOS NO BRASIL: processos que levam ao déficit habitacional, 2008. Disponível em: < REVISTA PP $20082 \mathrm{~F}$ 4.pmd> Acesso em: 03/07/2017 